\title{
Greenhouse Gas Emissions from Blackwater Septic Systems
}

\author{
Loi Tan Huynh, Hidenori Harada,* Shigeo Fujii, Lien Pham Hong Nguyen, Thu-Huong Thi Hoang, \\ and Hai Trung Huynh
}

Cite This: Environ. Sci. Technol. 2021, 55, 1209-1217

Read Online

ABSTRACT: Septic systems are potentially a significant source of greenhouse gases (GHGs). The present study investigated GHGs from the blackwater septic systems that are widely used especially in low- and middle-income countries. Ten blackwater septic tanks in Hanoi, Vietnam, were investigated using the floating chamber method. The average methane and carbon dioxide emission rates measured at the first compartment (65\% of total capacity) of the septic tanks were 11.92 and $20.24 \mathrm{~g} / \mathrm{cap} /$ day, respectively, whereas nitrous oxide emission was negligible. Methane emission rate was significantly correlated with septage oxidation-reduction potential (ORP) $(R=-0.67, p=0.034)$,

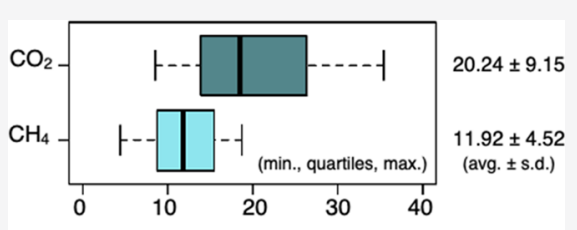

GHG emission rate from the first compartment of blackwater septic systems ( $\mathrm{g} / \mathrm{cap} /$ day) chemical oxygen demand mass $(R=0.78, p=0.007)$, and biochemical oxygen demand mass $(R=0.78, p=0.008)$, whereas it was not significantly correlated with water temperature $(R=0.26, p=0.47)$ and dissolved oxygen $(R=-0.59, p=0.075)$ within the limited range: $30.6-31.7{ }^{\circ} \mathrm{C}$ and $0.03-0.34 \mathrm{mg}-\mathrm{O}_{2} / \mathrm{L}$. The methane emission rates from septic tanks accumulating septage for $>5$ years were significantly higher than those at $0-5$ years $(p=0.016)$. These results suggest that lower ORP and higher biodegradable carbon mass, in association with longer septage storage periods are key conditions for methane emissions. To the best of our knowledge, this is the first study to characterize GHG emissions from septic systems.

\section{INTRODUCTION}

Septic systems are one of the major onsite sanitation facilities that were used by 1.5 billion people in $2017 .{ }^{1}$ They are widely used in urban and periurban areas of many low- and middleincome countries; ${ }^{2}$ for example, the proportion of households with septic systems in Hanoi, Vietnam, ${ }^{3}$ Hue, Vietnam, ${ }^{4}$ Mandalay, Myanmar, ${ }^{5}$ and Kota Surakarta, Indonesia, ${ }^{6}$ are 84, 80,90 , and $86 \%$, respectively. The design of septic systems can differ depending on the region, but they typically consist of a septic tank and soil absorption field, also known as an infiltration field or a soil treatment unit, while septic systems in urban areas of low- and middle-income countries often have no soil absorption field and the effluent discharges into leach pits or open drains. Due to the accumulation of organic matter under anaerobic conditions, septic systems produce greenhouse gases (GHGs). 7,8

In 1999, the United States Environmental Protection Agency (USEPA) estimated the global methane $\left(\mathrm{CH}_{4}\right)$ emissions from septic systems as $3.0 \mathrm{Tg}-\mathrm{CH}_{4} /$ year, which accounted for $10.4 \%$ of the global $\mathrm{CH}_{4}$ emissions from domestic wastewater. ${ }^{9}$ This result indicated that the emissions from septic systems are not negligible. Based on this estimation, the Intergovernmental Panel on Climate Change (IPCC), in 2007, proposed a $\mathrm{CH}_{4}$ emission factor of septic systems as $25.5 \mathrm{~g}-\mathrm{CH}_{4} / \mathrm{cap} /$ day, which allows the inclusion of GHG emissions from septic systems into global GHG emissions. ${ }^{10}$ This emission factor assumed a stoichiometric relationship between total biochemical oxygen demand (BOD) loading in domestic wastewater and $\mathrm{CH}_{4}$ emission from septic systems, and it is currently used to estimate GHG emissions from the wastewater sector worldwide. ${ }^{11}$ However, the stoichiometric relationship used in the IPCC emission factor for septic systems was actually derived from an emission rate study of anaerobic lagoons, ${ }^{12}$ not from septic systems themselves. The information about GHG emissions from septic systems is currently limited, although a large section of the population is using septic systems globally.

Septic systems vary in design and operating conditions. Septic systems in low- and middle-income countries often consist of a septic tank only and receive only blackwater, whereas graywater is often directly discharged to open drains. ${ }^{13,14}$ This type of system may have lower influent organic loading than septic systems which receive domestic wastewater including black and graywater possibly including food waste from a macerator in a sink. ${ }^{15}$ Septic systems have the potential to pose health and environmental risks if not operated properly as experienced in high-income countries; $^{16,17}$ however, the operating conditions are often worse in low- and middle-income countries, resulting in lower levels of performance and functionality. ${ }^{18}$ For example, in Hanoi, Vietnam, the average septage storage period (the number of years since the last emptying or since septic tank construction if the tanks had never been emptied) was 8.1 years, and some

Received: May 28, 2020

Revised: December 18, 2020

Accepted: December 23, 2020

Published: January 6, 2021 
households had not emptied their tanks for 20 years, resulting in low settling rates of settleable solids. ${ }^{19}$ Further, septic systems in low- and middle-income countries are often located in tropical climates and operate under higher temperatures than those in high-income countries with more temperate climates. Hence, in low- and middle-income countries, long septage storage periods and high temperatures might positively influence GHG emissions, whereas less organic loading caused by receiving only blackwater might negatively influence it. However, little is known about GHG emissions from blackwater septic systems, especially in low- and middleincome countries.

This study investigated the emission rates of GHGs, namely, $\mathrm{CH}_{4}$, carbon dioxide $\left(\mathrm{CO}_{2}\right)$, and $\mathrm{N}_{2} \mathrm{O}$, from septic systems in Hanoi, Vietnam, which are composed only of septic tanks and receive only blackwater. Ten septic tanks were investigated by onsite monitoring of GHG emission rates using the floating chamber method. The influence of septic tank conditions such as sludge compositions, effluent quality, and emptying conditions was also investigated. To the best of our knowledge, this is the first study to characterize GHG emissions from septic systems.

\section{MATERIALS AND METHODS}

2.1. Study Area. Hanoi is located in the northern part of Vietnam, and has a population of 8.05 million. ${ }^{20}$ The city has a subtropical monsoon climate with a monthly average temperature of $26-33{ }^{\circ} \mathrm{C}$ in summer (from May to August) and 14$19{ }^{\circ} \mathrm{C}$ in winter (from November to February). ${ }^{20}$ Septic systems are the main type of onsite sanitation facility in Hanoi as they are present in $84 \%$ of households. ${ }^{3}$ A major proportion of these septic systems discharge their effluent into drainage or sewer systems, which cover $80-90 \%$ of the city. ${ }^{21}$ However, the coverage of centralized wastewater treatment plants is limited to approximately $33.4 \%$ of the city's population, ${ }^{22}$ meaning a large portion of septic system effluent is discharged into water bodies through drainage or sewer systems.

Most septic systems in Hanoi consist only of septic tanks and receive only blackwater. ${ }^{21,22}$ Septic tanks are required to have at least $3.0 \mathrm{~m}^{3}$, with a hydraulic retention time (HRT) in the range of 1.0-2.8 days for a household with two bedrooms (five users) according to the national guidelines of Vietnam. ${ }^{23}$ Pham reported that the average and standard deviation of septic tank size in Hanoi was $3.4 \pm 1.2 \mathrm{~m}^{3}$ with three compartments, and the average number of users was five. ${ }^{24}$ The chemical oxygen demand (COD) and suspended solids (SS) removal performance of septic tanks in Hanoi was low in most cases. 25

2.2. Surveyed Septic Tanks. Ten septic tanks (ST1ST10) were investigated in the urban area of Hanoi (see details in Table S1). The surveyed septic tanks received only blackwater from cistern-flush toilets. Of these, nine had three compartments and one had two compartments. The average and standard deviation of the effective volume of septic tanks was $2.3 \pm 0.7 \mathrm{~m}^{3}$ (average \pm standard deviation), of which the first compartment accounted for $65 \%\left(1.5 \pm 0.6 \mathrm{~m}^{3}\right)$. Out of the 10 septic tanks, seven had never been emptied and the septage storage periods were 7-19 years based on the building construction records. The remaining three septic tanks had been emptied and the septage storage periods were 3 years 11 months to 4 years based on household owners' memories. The effluent of these septic tanks is discharged into the sewer system.
2.3. Monitoring of Water Flow, Septage, and Effluent. 2.3.1. Experimental Setup. All surveyed septic tanks were built under the houses. There was originally no emptying hole for desludging. In Hanoi, septage is emptied from the first compartment commonly by breaking the floor of the house to make a hole for the hose of the emptying truck at any possible location when the septic tanks are emptied. Since all house owners of ST1-ST10 planned to empty septic tanks using the common method, we made a hole with a cover for the first compartment, which was used for sampling inside septic tanks in the present study. Thus, we could not control the sampling location and could not collect samples from the second and third compartments; this is a limitation of the sampling of the present study.

Due to the difficulties in the experimental setup inside the septic tanks under use, the present study used only ST1 and ST2 to monitor water flow and to collect effluent samples. All septic tanks, ST1-ST10, were used to sample septage (i.e., the total of bottom sludge, liquid, and scum layers) and emitted gas. The experimental setup used for ST1 and ST2 is shown in Figure 1. As septic tanks in low- and middle-income countries

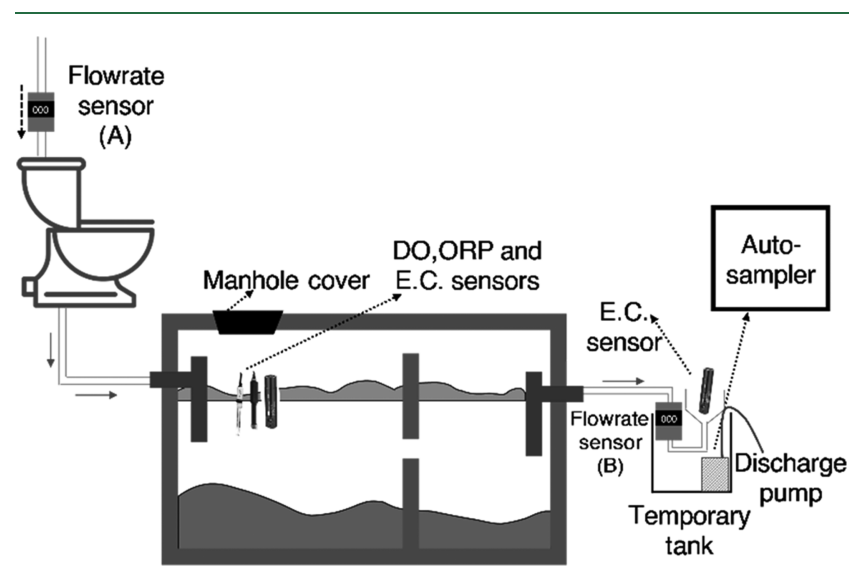

Figure 1. Experimental setup of sensor and autosampler for water and septage monitoring.

are often suspected of leakage, ${ }^{21,26}$ the present study checked the water balance by quantifying the influent and effluent with water flow rate sensors (FD-M5AT, Keyence) installed at the inlet of every toilet water tank (sensor A) and at the outlet of septic tanks (sensor B) (Figure 1).

A temporary tank $(4.5 \mathrm{~L})$ was installed at the outlets of ST1 and ST2 for effluent online monitoring and sampling. After passing the flow sensor (B), the effluent overflowed from the cone $(0.37 \mathrm{~L})$ to the temporary tank. Electrical conductivity (E.C.) and water temperature of the effluent were continuously monitored by an E.C. logger (U-24, HOBO). The cone was cleaned several times per day to avoid the settling of solids. An autosampler with cooling preservation by ice inside the bottle container (3700, Teledyne ISCO) was connected to the temporary tank to collect effluent samples.

For ST1-ST10, a dissolved oxygen (DO) (HQ30D, HACH-LDO), oxidation-reduction potential (ORP) (930010D, HORIBA), and E.C. logger (U-24, HOBO) were installed inside the first compartment of the septic tank at 25 $\mathrm{cm}$ below water surface under the emptying hole cover.

2.3.2. Effluent and Septage. For ST1 and ST2, two sampling campaigns of effluent were conducted, i.e., daily composite samplings and hourly samplings. Daily composite 
sampling of effluent was performed from June 18 to July 3, 2019 (16 days), for ST1, and from July 13 to July 20, 2019 (7 days), for ST2 during the summer season. For daily composite sampling, at $2 \mathrm{~h}$ intervals, $500 \mathrm{~mL}$ of effluent wastewater was collected by the autosampler, and a composite was produced. Hourly samples were obtained on July 1 and 19, 2019 for ST1 and ST2, respectively. Sensor data at the outlet of septic tanks were collected during the same period of composite sampling.

Septage was sampled from ST1-ST10. In the present study, septage was defined as the total of bottom sludge (settled solids), liquid, and scum layers in the septic tanks. To avoid changing the conditions inside the septic tanks, the septage sampling was conducted after the gas sampling mentioned below. Septage was sampled through a hole using a core sampling device with a one-way valve. The device is transparent, which allows the thickness of each layer to be measured. All of the samples were kept on ice for transportation to the laboratory. For ST1 and ST2, sensor data inside septic tanks were collected during the same period of composite sampling of the effluent. For the remaining (ST3-ST10), they were collected only during gas sampling.

The water quality of the effluent and septage was analyzed using standard methods (APHA, 2005) for the following parameters: $\mathrm{pH}$, E.C., $\mathrm{BOD}_{5}, \mathrm{SS}$, volatile suspended solids (VSS), nitrate nitrogen $\left(\mathrm{NO}_{3}-\mathrm{N}\right)$, nitrite nitrogen $\left(\mathrm{NO}_{2}-\mathrm{N}\right)$, total phosphorus (T-P), and phosphate $\left(\mathrm{PO}_{4}-\mathrm{P}\right)$. $\mathrm{COD}_{\mathrm{Cr}}$, total nitrogen ( $\mathrm{T}-\mathrm{N})$, and ammonium nitrogen $\left(\mathrm{NH}_{4}-\mathrm{N}\right)$ were analyzed by $\mathrm{HACH}$ methods. All of the effluent and septage sample analyses were duplicated every five samples, and the errors were within $10 \%$. For duplicated samples, the average of two measurements was used as a result.

2.4. Monitoring of Emitted Gas. 2.4.1. Gas Sample Collection. Although there were ventilation pipes in the septic tanks, the gas inside the tanks often leaked through somewhere other than the pipes. This study, therefore, used the floating chamber method ${ }^{27,28}$ for gas emission monitoring.

The floating chamber (see Text S1) was inserted on the septage surface in the first compartment of the septic tank through a manhole before emptying the septage. There was a scum layer in the first compartment of the septic tanks except ST6 and ST10; the thickness of the scum layer ranged between 2.1 and $7.5 \mathrm{~cm}$. As the presence of scum layer did not affect the emission rate measurement in Diaz-Valbuena et al., ${ }^{29}$ the present study placed the chamber on the scum to avoid disturbance of septage. Gas samples were collected from 9:30 AM to 11:30 AM each day. During sampling, toilets were not used, and no disturbance was observed inside the first compartment. Once the chamber was in place, 24-mL of gas was withdrawn from the chamber through the sampling tube connected by a syringe at 10 -min intervals, for $60 \mathrm{~min}$. The fan inside the chamber was activated for $5 \mathrm{~s}$ right before sampling. These gas samples were used to analyze $\mathrm{CO}_{2}$ and $\mathrm{CH}_{4}$. At the last sampling $(t=60 \mathrm{~min}), 12-\mathrm{mL}$ of sample and $1-\mathrm{L}$ were additionally collected; the former was in a syringe for $\mathrm{N}_{2} \mathrm{O}$ analysis, and the latter in a Teflon bag for ammonia $\left(\mathrm{NH}_{3}\right)$ analysis. After the sampling, $\mathrm{CO}_{2}$, carbon monoxide ( $\mathrm{CO}$ ), and $\mathrm{CH}_{4}$ concentrations were also analyzed using a portable gas analyzer (PG300, HORIBA) connected to the chamber for cross-checking. All syringes and Teflon bags with gas were sealed with parafilm and transported on ice to the laboratory. The gas samples were transferred into serum vials, kept in a refrigerator, and analyzed within $24 \mathrm{~h}$. Gas sampling was conducted two times with a 1-week interval for ST1 (June 22 and 29, 2019) and ST2 (July 13 and 20, 2019), and emissions at two different days were compared for each septic system. For ST3-ST10, gas sampling was performed one time for each septic tank (June 23 to July 27, 2019). The present study also screened the amount of dissolved gas in the effluent. For the dissolved gas analysis, effluent samples were additionally collected from the outlet pipes of ST1 (June 22, 2019) and ST2 (July 13, 2019). Dissolved gas was obtained from the effluent samples based on the salting-out method. ${ }^{30}$

2.4.2. Sample Analysis. Concentrations of $\mathrm{CH}_{4}, \mathrm{CO}_{2}$, and $\mathrm{N}_{2} \mathrm{O}$ in the collected samples were determined using a gas chromatograph (Shimadzu GC-2014) with a flame ionization detector, thermal conductivity detector, and electron capture detector, respectively. The operating temperature of these detectors was $200{ }^{\circ} \mathrm{C}$. The retention times for $\mathrm{CH}_{4}, \mathrm{CO}_{2}$, and $\mathrm{N}_{2} \mathrm{O}$ were 5.251, 8.976, and $10.617 \mathrm{~min}$, respectively. The $\mathrm{NH}_{3}$ concentration was analyzed by the acid absorption method (EPA-17 method). Dissolved gas was collected from the effluent based on the salting-out method. ${ }^{30}$ The $\mathrm{CH}_{4}$ and $\mathrm{CO}_{2}$ concentrations of the dissolved gas were analyzed with a portable gas analyzer (PG300, HORIBA). All of the gas sample analyses were duplicated every 10 samples, and the errors were within $9 \%$. For duplicated samples, the average of two measurements was used as a result.

2.4.3. Calculation of Gas Emissions. The gas emissions rates $\left(\mathrm{mg} / \mathrm{m}^{3}\right.$-gas $\left./ \mathrm{min}\right)$ were determined based on the floating chamber measurements by plotting $[X]_{t}$ against incubation time (the sampling period of the floating chamber), where $[X]_{t}$ is the inner gas concentration of the floating chamber $\left(\mathrm{mg} / \mathrm{m}^{3}\right)$ at time $t$ ( $\mathrm{min})$. Although nonlinear fittings were also considered, the data were fitted well to linear plotting within $60 \mathrm{~min}\left(R^{2}=0.93-0.99\right)$. The slope of a linear fit of the data provides the emission rate $\left(\mathrm{mg} / \mathrm{m}^{3}\right.$-gas $/ \mathrm{min}$ ) (Figure $\mathrm{S} 1$ ). These emissions rates were converted to emission rates per capita (g/cap/day) through eq 1

$$
E=\frac{m \times 1440 \times 10^{-3} \times V_{\mathrm{FC}} \times A_{\text {comp }}}{A_{\mathrm{FC}} \times n}
$$

where $E$ is the emission rate per capita (g/cap/day); $m$ is the emission rate based on the inner concentration of the floating chamber $\left(\mathrm{mg} / \mathrm{m}^{3}\right.$-gas/min $) ; 1440$ is minutes in a day $(\mathrm{min} /$ day); $V_{\mathrm{FC}}$ is the chamber volume $\left(\mathrm{m}^{3}\right)=2.65 \mathrm{~L} ; A_{\text {comp }}$ is the area of the compartment $\left(\mathrm{m}^{2}\right) ; A_{\mathrm{FC}}$ is the area covered by the floating chamber $\left(\mathrm{m}^{2}\right)$; and $n$ is the household size (cap).

The septic tanks typically found in Hanoi consist of two or three compartments. The present study monitored the emissions from the first compartment only; however, the second and third compartments may potentially also produce GHGs since the effluent still contains organic pollutants. To estimate the likely potential spread of total GHG emissions from the septic tanks, we calculated three scenarios based on the observed fluxes from the first compartment: (i) a minimum emission scenario whereby total emissions were calculated assuming that only the first compartment was emitting GHGs (zero emissions from any subsequent compartment, eq 2), (ii) a maximum scenario whereby total emissions were calculated assuming that the entire surface areas of all septic tank compartments were emitting GHGs at the same per-area emission rate observed over the first compartment (eq 3), and (iii) a middle scenario in between these extremes whereby conversion factors observed in previous studies on septic systems in the United States between the first and second 
Table 1. Septage Composition and Relevant Septic Tank Conditions in the First Compartment of ST1-ST10

\begin{tabular}{|c|c|c|c|c|c|c|c|c|c|c|c|c|}
\hline ID & $\begin{array}{l}\text { liquid } \\
\text { temp } \\
\left({ }^{\circ} \mathrm{C}\right)\end{array}$ & $\begin{array}{l}\mathrm{COD}_{\mathrm{cr}} \\
\text { septage } \\
(\mathrm{mg} / \mathrm{L})\end{array}$ & $\begin{array}{c}\mathrm{COD}_{\mathrm{cr}} \text { mass } \\
\text { of septage } \\
(\mathrm{g} / \mathrm{tank})\end{array}$ & $\begin{array}{l}\mathrm{COD}_{\mathrm{cr}} \text { of } \\
\text { liquid layer } \\
(\mathrm{mg} / \mathrm{L})\end{array}$ & $\begin{array}{c}\mathrm{BOD}_{5} \\
\text { septage } \\
(\mathrm{mg} / \mathrm{L})\end{array}$ & $\begin{array}{c}\mathrm{BOD}_{5} \text { mass } \\
\text { of septage } \\
(\mathrm{g} / \mathrm{tank})\end{array}$ & $\begin{array}{c}\mathrm{SS} \\
(\mathrm{mg} / \mathrm{L})\end{array}$ & $\begin{array}{c}\text { VSS } \\
(\mathrm{mg} / \mathrm{L})\end{array}$ & $\begin{array}{c}\mathrm{DO} \\
(\mathrm{mg} / \mathrm{L})\end{array}$ & $\begin{array}{l}\mathrm{ORP}^{a} \\
(\mathrm{mV})\end{array}$ & $\begin{array}{l}\text { septage } \\
\text { storage } \\
\text { period } \\
\text { (year) }\end{array}$ & $\begin{array}{c}\text { volume of } \\
\text { settled } \\
\text { solids }\left(\mathrm{m}^{3}\right)\end{array}$ \\
\hline ST1 & 31.1 & 5800 & 10585 & 589 & 4607 & 8407 & 5895 & 3665 & 0.03 & -346 & 3.9 & 0.81 \\
\hline ST2 & 31.4 & 15892 & 15240 & 969 & 12782 & 12257 & 7805 & 6980 & 0.03 & -434 & 10.0 & 0.67 \\
\hline ST3 & 31.7 & 17576 & 21913 & 1032 & 14964 & 14841 & 9264 & 5785 & 0.18 & -479 & 14.0 & 0.91 \\
\hline ST4 & 31.4 & 9584 & 21815 & 1504 & 8571 & 19509 & 8830 & 7064 & 0.26 & -305 & 7.0 & 1.71 \\
\hline ST5 & 31.1 & 16758 & 27581 & 1498 & 13001 & 21398 & 9870 & 7983 & 0.19 & -489 & 18.0 & 1.05 \\
\hline ST6 & 31.2 & 7820 & 8399 & 805 & 6621 & 7111 & 6020 & 5418 & 0.31 & -237 & 4.0 & 1.00 \\
\hline ST7 & 31.0 & 16286 & 30822 & 818 & 13529 & 28927 & 6788 & 5430 & 0.17 & -334 & 9.0 & 1.45 \\
\hline ST8 & 31.0 & 17220 & 22768 & 1820 & 13076 & 17289 & 9934 & 7679 & 0.08 & -445 & 19.0 & 1.25 \\
\hline ST9 & 30.6 & 13068 & 29500 & 1126 & 10924 & 24660 & 9067 & 6373 & 0.21 & -391 & 14.0 & 1.13 \\
\hline ST10 & 30.1 & 6250 & 5110 & 703 & 5013 & 4099 & 5573 & 4904 & 0.34 & -230 & 4.0 & 0.25 \\
\hline & 31.1 & 12625 & 19373 & 1086 & 10309 & 16231 & 7905 & 5838 & 0.18 & -369 & 10.3 & 1.02 \\
\hline & 0.4 & 4790 & 9087 & 401 & 3810 & 80056 & 1710 & 1541 & 0.11 & 94 & 5.7 & 0.41 \\
\hline
\end{tabular}

${ }^{a} \mathrm{ORP}_{\text {SHE }}(\mathrm{mV})=\mathrm{ORP}+206-0.7(t-25)$, where $t$ is the temperature $\left({ }^{\circ} \mathrm{C}\right) .{ }^{b}$ Note: ST1 and ST2 are the average values of two septage samples at different days except the septage storage period and hydraulic retention time (HRT). ST3-ST10 show the results from each sample. Detailed composition data are shown in Table S3.

compartments were used to extrapolate observed emissions from the first chamber to subsequent compartments (see below).

$$
\begin{aligned}
& E_{\text {total,min }}=E_{1 s t} \\
& E_{\text {total,max }}=E_{1 s t} \times \frac{A_{\text {total }}}{A_{1 s t}}
\end{aligned}
$$

where $E_{\text {total,min }}$ is the minimum estimate of the total emission rate from all compartments (g/cap/day); $E_{\text {total,max }}$ is the maximum estimate of the total emission rate from all compartments ( $\mathrm{g} / \mathrm{cap} / \mathrm{day}) ; E_{1 \mathrm{st}}$ is the emission rate from the first compartment ( $\mathrm{g} / \mathrm{cap} /$ day); $A_{\text {total }}$ is the total area of the septic tank $\left(\mathrm{m}^{2}\right)$; and $A_{1 \mathrm{st}}$ is the area of the first compartment $\left(\mathrm{m}^{2}\right)$.

According to a previous study, ${ }^{29}$ the ratios of the emission rates per area from the second compartment to those from the first compartments were 0.42 and 0.55 (average) for $\mathrm{CH}_{4}$ and $\mathrm{CO}_{2}$, respectively. Although the septic tank design and usage are different between this previous study and the present study, since we could not find any reference on this ratio, and the present study assumed the same ratio between the first compartment and the second/third compartment, the emission from all compartments was calculated using eq 4 as a middle estimate of the total emission rate from all compartments.

$$
E_{\text {total,mid }}=E_{1 s t}+E_{1 s t} \times R \times \frac{A_{2 \mathrm{nd}, 3 \mathrm{rd}}}{A_{1 \mathrm{st}}}
$$

where $E_{\text {total,mid }}$ is the middle estimate of the total emission rate from all compartments ( $\mathrm{g} / \mathrm{cap} / \mathrm{day}) ; R$ is the ratio of the emission rates per area from the second compartment to those from the first compartment $(-)$; and $A_{2 \text { nd,3rd }}$ is the total area of the second and third compartments $\left(\mathrm{m}^{2}\right)$.

\section{RESULTS AND DISCUSSION}

3.1. Septic Tank Conditions. 3.1.1. Water Balance. According to the water volume recorded by the water flow rate sensors in ST1 and ST2, the ratio between influent and effluent was $0.95-0.98$. Since this small gap between influent and effluent flows can represent the volume of human waste, we concluded that these two septic tanks presented no water leakage. HRTs were 17.1 and 5.2 days for ST1 and ST2, respectively. The great difference between these HRTs stemmed from the different effective volume of the septic tanks $\left(1.42 \mathrm{~m}^{3}\right.$ for ST1 and $0.47 \mathrm{~m}^{3}$ for ST2).

3.1.2. Effluent and Septage Composition. The effluent characteristics and pollutant loadings of ST1 and ST2 are summarized in Table S2. The average COD, BOD, and SS concentrations of ST1 were 564, 389, and $39 \mathrm{mg} / \mathrm{L}$, whereas those of ST2 were 803, 544, and $173 \mathrm{mg} / \mathrm{L}$, respectively. These are within the range of previous studies in Hanoi. ${ }^{22,24} \mathrm{NH}_{4}-\mathrm{N}$ accounted for a major part of nitrogen in the effluent, similar to previous studies, ${ }^{22,26}$ indicating that nitrification was not a dominant process in the septic tanks. Hourly effluent quality results show the coefficients of variation $(\mathrm{CV})$ of COD, BOD, SS, and VSS were 7.1, 9.3, 7.6, and 9.1\% for ST1 and 1.1, 2.9, 3.7 , and $3.9 \%$ for ST2, respectively, indicating the diurnal stability of the effluent quality of ST1 and ST2. Higher pollutant concentrations in the effluent of ST2 might be associated with the longer septage storage period and shorter HRTs in ST2 (10 years, 5.2 days) than ST1 (3.9 years, 17.1 days), causing overaccumulation of solid matter and lower settling and skimming function of solid matter. ${ }^{19}$ However, the impact of septic tank conditions on the effluent quality was out of the scope of this study.

Table 1 shows the septage composition of ST1-ST10 (detailed in Table S3). The surveyed septic tanks were under anaerobic conditions as clearly indicated by low DO and ORP. Moreover, $\mathrm{pH}$ and liquid temperature were within the range for optimum mesophilic anaerobic digestion (neutral $\mathrm{pH}$; $25-$ $\left.35{ }^{\circ} \mathrm{C}\right) .^{7}$ The septage composition in the present study was comparable to previous studies in Hanoi (COD: $20290 \pm$ $15200 \mathrm{mg} / \mathrm{L}^{24}$ and $24900 \pm 14200 \mathrm{mg} / \mathrm{L} ;{ }^{31}$ VSS: $13070 \pm$ $11430 \mathrm{mg} / \mathrm{L}^{24}$ (average \pm standard deviation)). $\mathrm{NH}_{4}-\mathrm{N}$ concentrations were $390 \pm 155 \mathrm{mg} / \mathrm{L}$, which was a major form of soluble nitrogen in the septage (soluble T-N: $472 \pm 140$ $\mathrm{mg} / \mathrm{L}) . \mathrm{NO}_{3}-\mathrm{N}$ and $\mathrm{NO}_{2}-\mathrm{N}$ concentrations in the septage were as low as $6.0 \pm 1.1$ and $2.4 \pm 0.6 \mathrm{mg} / \mathrm{L}$, respectively, again indicating that nitrification was not a dominant process in the septic tanks.

In addition to the above results obtained from the core samples of septage of ST1-ST10, ORP, temperature, E.C., and DO were continuously monitored by online sensors for ST1 
(16 days) and ST2 (7 days). The CV of hourly ORP, temperature, E.C., and DO fluctuations inside these two septic tanks were, respectively, 5.4, 3.3, 11.9, and $30.0 \%$ for ST1, and $2.3,1.2,6.2$, and $43.7 \%$ for ST2; the CV of DO was high but its values were stable within $0.03-0.34 \mathrm{mg} / \mathrm{L}$. These results indicate the septage conditions inside ST1 and ST2 were diurnally stable, although the present study did not investigate the stability for ST3-ST10 due to the difficulties of sensor setup inside septic tanks.

3.2. GHG Concentrations. $\mathrm{CH}_{4}$ and $\mathrm{CO}_{2}$ concentrations in the floating chamber were plotted against incubation time, and a linear regression analysis was conducted for each septic tank (Figure S1). The $R^{2}$ values for ST1-ST10 were within 0.93-0.99 (Table S4), thus indicating that inner gas concentrations successfully increased and there was no unexpected leakage inside the floating chamber during the 60 min monitoring. The accumulated $\mathrm{CH}_{4}$ and $\mathrm{CO}_{2}$ concentrations at $t=60 \mathrm{~min}$ for 10 septic tanks were 653725579 and 4577-13 541 ppm, respectively. In contrast, $\mathrm{N}_{2} \mathrm{O}$ concentration was smaller than $1.0 \mathrm{ppm}$, comparable to a previous study on septic tanks in the United States. ${ }^{29} \mathrm{CO}$ concentration was approximately similar to ambient concentration, and $\mathrm{NH}_{3}$ concentration was almost less than $0.5 \mathrm{ppm}$ (Table S5). Due to these negligible concentrations, the following discussion excludes $\mathrm{CO}, \mathrm{NH}_{3}$, and $\mathrm{N}_{2} \mathrm{O}$.

3.3. $\mathrm{CH}_{4}$ and $\mathrm{CO}_{2}$ Emission Rates. As shown in Figure 2, the average $\mathrm{CH}_{4}$ and $\mathrm{CO}_{2}$ emission rates from the first

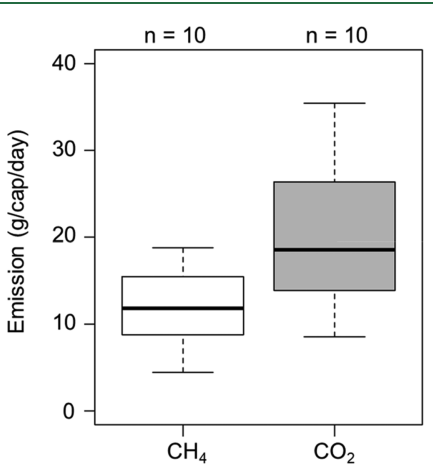

Figure 2. $\mathrm{CH}_{4}$ and $\mathrm{CO}_{2}$ emission rates from the first compartment of blackwater septic tanks in Hanoi $(n=10)$. Boxplots indicate the median and interquartile ranges (IQRs) with whiskers extending up to $1.5 \times \mathrm{IQR}$.

compartment of ST1-ST10 were $11.92 \pm 4.52$ and $20.24 \pm$ $9.15 \mathrm{~g} / \mathrm{cap} /$ day (average \pm standard deviation), respectively. $\mathrm{CV}$ and ratios of maximum to minimum of the emission rates from the first compartment were $37.9 \%$ and 4.3 for $\mathrm{CH}_{4}$, and $45.2 \%$ and 4.1 for $\mathrm{CO}_{2}$, respectively. These results indicate a large variability in GHG emissions from individual septic tanks, which is potentially reflected by the large variability in the inside conditions of septic tanks, as summarized in Table 1. C$\mathrm{CO}_{2}$ and $\mathrm{C}-\mathrm{CH}_{4}$ of the emission rates showed a linear relationship and the average $\mathrm{C}-\mathrm{CO}_{2} / \mathrm{C}-\mathrm{CH}_{4}$ ratio in this study was 0.37:0.63 (Figure S2). Assuming the substrates inside septic tanks can be represented by $\mathrm{C}_{6} \mathrm{H}_{12} \mathrm{O}_{4}$ or $\mathrm{C}_{6} \mathrm{H}_{12} \mathrm{O}_{6}$, the theoretical ratio of $\mathrm{C}-\mathrm{CO}_{2} / \mathrm{C}-\mathrm{CH}_{4}$ for anaerobic digestion is 0.4:0.6 or $0.5: 0.5$, respectively. ${ }^{7}$ Therefore, the ratio in this study is in line with theoretical ratios, which indicates that organics in septic tanks were mainly decomposed by anaerobic digestion.
Based on the measured emission rates from the first compartment of ST1-ST10, the minimum, middle, and maximum estimates of emission rates from all compartments of ST1-ST10 were calculated based on eqs $2-4$ as $11.92 \pm$ 4.52 (average \pm standard deviation), $13.64 \pm 5.05$, and 16.00 $\pm 5.81 \mathrm{~g} / \mathrm{cap} /$ day for $\mathrm{CH}_{4}$, and $20.24 \pm 9.15,24.00 \pm 10.34$ and $27.06 \pm 11.29 \mathrm{~g} / \mathrm{cap} /$ day for $\mathrm{CO}_{2}$, respectively. Even the minimum estimates of the $\mathrm{CH}_{4}$ emission rates from all compartments in the present study were comparable to the $\mathrm{CH}_{4}$ emission rates from all compartments in Diaz-Valbuena et al. $^{29}(11 \pm 2.2 \mathrm{~g} / \mathrm{cap} /$ day $)$ and Truhlar et al. ${ }^{32}(11 \pm 12 \mathrm{~g} /$ cap/day), whereas even the maximum estimates in the present study were significantly smaller than the IPCC $(25.5 \mathrm{~g} / \mathrm{cap} /$ day, ${ }^{10} p<0.001, t$-test $)$ and USEPA $\left(27.1 \mathrm{~g} /\right.$ cap $/$ day, ${ }^{33} p<$ $0.001, t$-test) emission factors. The potential reasons for these significant differences and the variability within our samples are discussed in Section 3.4.

Among the 10 surveyed septic tanks, effluent was collected from ST1 and ST2, for which dissolved $\mathrm{CH}_{4}$ in the effluent was monitored with effluent flow rate. The average dissolved $\mathrm{CH}_{4}$ concentration was $0.22 \mathrm{mg} / \mathrm{L}$ for ST1 and ST2. Based on the solubility of $\mathrm{CH}_{4}$ in distilled water $(0.0009 \mathrm{mg} / \mathrm{L}),{ }^{34} \mathrm{CH}_{4}$ was oversaturated in the effluent by $24444 \%$ to enable comparison with other anaerobic digestion studies in lagoons (260$128420 \%$ of saturation). ${ }^{35}$ According to the average flow rate of the effluent, $18.9 \mathrm{~L} / \mathrm{cap} /$ day for ST1 and ST2, this dissolved $\mathrm{CH}_{4}$ concentration was converted to discharged $\mathrm{CH}_{4}$ rate in the effluent, at $3.68 \mathrm{mg}$ dissolved/cap/day. This dissolved $\mathrm{CH}_{4}$ in the effluent accounted for only $0.04 \%$ (ST1) and $0.04 \%$ (ST2) of the total $\mathrm{CH}_{4}$ emitted from the first compartment of septic tanks. Therefore, the amount of dissolved $\mathrm{CH}_{4}$ was negligible.

As Diaz-Valbuena et al. $^{29}$ reported, the proportion of dissolved $\mathrm{CH}_{4}$ in the effluent from septic tanks was small compared to the $\mathrm{CH}_{4}$ gas emission from septic tanks in the United States $(0-11 \%)$; the present study also indicated the limited amount of $\mathrm{CH}_{4}$ dissolved in the effluent. Still, the effluent of ST1 and ST2 in the present study contained a lot of organics: $564-803 \mathrm{mg} / \mathrm{L}$ and $50.9-84.5 \mathrm{~g} / \mathrm{day}$ for COD, and 389-544 mg/L and 29.7-45.6 g/day for BOD. These organics are potentially converted to the GHGs in the post-treatment of septic tanks. Significant GHG emissions from soil treatment units as a post-treatment process of septic tanks were reported by Truhlar et al. ${ }^{32}$ and Somlai et al., ${ }^{36}$ mainly in the form of $\mathrm{CO}_{2}$. In the present study, septic tank effluent was discharged to sewers. Considering $66.6 \%$ of sewers were not covered by centralized wastewater treatment plants and connected to water bodies directly, GHGs are potentially emitted in sewer or in water bodies in the study site. Further studies are required on the post-treatment emission in sewers or in water bodies.

3.4. Variability in Methane Emission. Methane emissions can be affected by the conditions inside the septic tanks. Liquid temperature, ORP, DO, and COD mass of ST1ST10 were $30.6-31.7{ }^{\circ} \mathrm{C},-489$ to $-230 \mathrm{mV}, 0.03-0.34 \mathrm{mg} /$ $\mathrm{L}$, and 5110-30 $822 \mathrm{~g} /$ tank, respectively (Table 1 ). The ORP values were comparable to the operational ORP range for sewage sludge fermentation $(-200$ to $-500 \mathrm{mV}) .{ }^{37}$ Regardless of the performance of pollutant removal, the inside conditions of the septic tanks such as low ORP and high COD mass of septage were suitable for anaerobic digestion.

The $\mathrm{CH}_{4}$ emission rates from the first compartment of ST1-ST10 were correlated with the 12 parameters of septage 

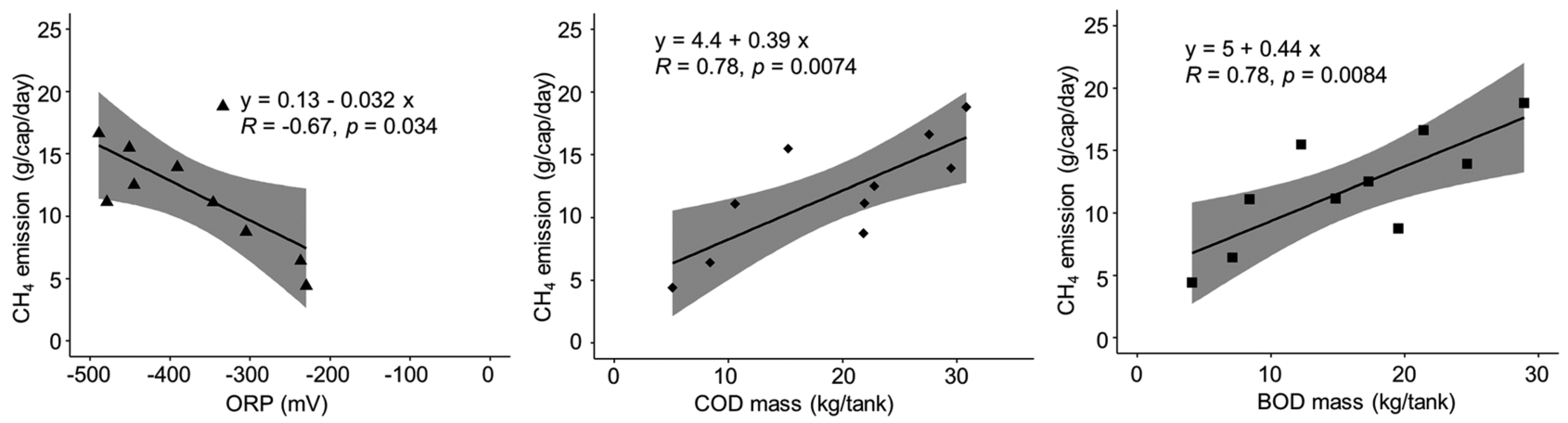

Figure 3. Correlation between $\mathrm{CH}_{4}$ emission rate and ORP, COD mass, and BOD mass of septage for septic tanks $(n=10)$. The black lines show linear trends, and the gray zones show $95 \%$ confidence intervals.
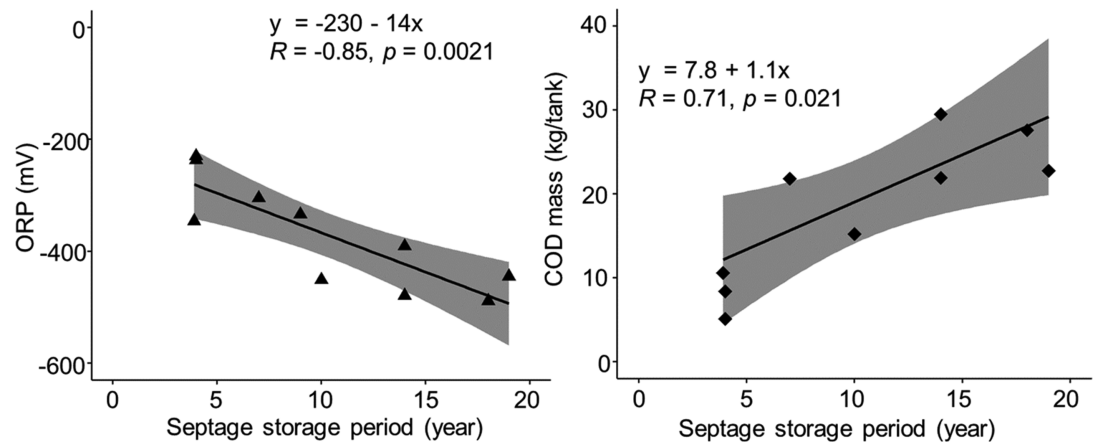

Figure 4. Correlation between septage storage period and ORP and COD mass of septage $(n=10)$. The black lines show linear trends, and the gray zones show $95 \%$ confidence intervals.
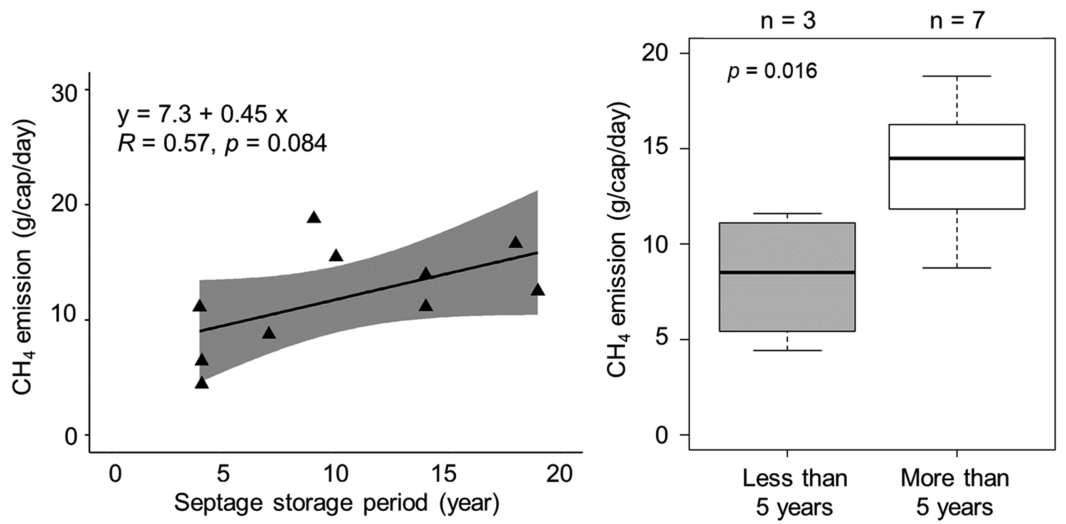

Figure 5. $\mathrm{CH}_{4}$ emission rates of the first compartments of septic tanks depending on septage storage period $(n=10)$. The black line (left) shows linear trends, and the gray zone (left) shows $95 \%$ confidence intervals; the boxplots (right) indicate the median and interquartile ranges (IQRs) with whiskers extending up to $1.5 \times \mathrm{IQR}$.

composition and septic tank conditions listed in Table 1. ORP, BOD mass, and COD mass significantly correlated with $\mathrm{CH}_{4}$ emissions, with $R$-values of $-0.67(p=0.034), 0.78$ ( $p=$ $0.007)$, and $0.78(p=0.008)$, respectively (Figure 3$)$. These correlations indicate that lower ORP and higher biodegradable carbon mass are key conditions for the emission of $\mathrm{CH}_{4}$ from septic tanks. DO, liquid temperature, and the volume of settled solids are also often considered as influential parameters for methane emissions but they were not correlated to $\mathrm{CH}_{4}$ emissions (DO: $R=-0.59, p=0.075$, liquid temperature: $R$ $=0.26, p=0.47$, volume of settled solids: $R=0.37, p=0.29$; Figure S3), possibly explained by the narrow range of $0.31 \mathrm{mg} /$ $\mathrm{L}$ for $\mathrm{DO}$ and $1.1{ }^{\circ} \mathrm{C}$ for liquid temperature. Further studies are required to determine the impact of DO and liquid temperature.
The changes in ORP, DO, COD mass, and BOD mass of ST1-ST10 can be partly explained by the septage storage period (Figures 4 and $S 4$ ). Septage storage period was strongly correlated with ORP $(R=-0.85, p=0.002)$ and moderately correlated with COD mass of septage $(R=0.71, p=0.021)$, whereas septage storage period was not significantly correlated with $\mathrm{DO}(R=-0.2, p=0.39)$ or BOD mass $(R=0.56, p=$ $0.09)$. These correlations indicate that the longer septage is stored, the more COD accumulates under highly reduced conditions, possibly causing a positive impact on $\mathrm{CH}_{4}$ production.

Although the correlation between emission rate and septage storage period was not significant $(R=0.57, p=0.084), \mathrm{CH}_{4}$ emission rates from the first compartment of septic tanks with longer storage periods (more than 5 years) were significantly 
higher than those with shorter storage periods ( $0-5$ years) ( $p$ $=0.016, t$-test $)$, as shown in Figure 5. Together with the correlation between septage composition and storage period, this result implies that longer septage storage periods lead to larger $\mathrm{CH}_{4}$ emissions. The effect of storage period on the increased emissions might be caused by the emissions from previous organic loading that has accumulated throughout the storage period. Additionally, it could be caused by the slow growth rate of methanogenic bacteria. ${ }^{7,26}$ The septage storage periods of septic tanks in South East Asia are often long, e.g., 6.2-14.2 years in Hanoi, ${ }^{19,24}$ an average of 14 years in Hue, Vietnam, ${ }^{4}$ and an average of 12.7 years in Mandalay, Myanmar. ${ }^{5}$ These very long septage storage periods primarily deteriorate the removal efficiency of organic pollutants (SS, COD, and BOD) due to overaccumulation of septage, causing malfunctioning to the settling and skimming processes. ${ }^{8,19}$ Furthermore, they would increase $\mathrm{CH}_{4}$ emissions from septic systems as indicated in the present study. In other words, if septic tanks are properly emptied, they will present improved pollutant removal and reduced GHG emissions from septic tanks. However, in Hanoi, 2-6\% of emptied septage is generally treated at an anaerobic digestion plant without biogas recovery, ${ }^{3,21}$ and the remaining is discharged to landfill sites without biogas recovery ${ }^{22}$ or illegally dumped in the urban environment, ${ }^{3}$ potentially causing GHG emissions at the treatment and disposal sites. Even if the emissions from septic tanks are reduced by proper emptying, the septage needs to be treated and disposed of in a GHG-mitigating manner to reduce overall emissions.

A notable difference between the septic tanks of the previous studies in the United States ${ }^{29,32}$ and the present study is the type of influent: the former received domestic wastewater including black and graywater, whereas the latter received only blackwater. This difference likely caused the greater organic loading input to the septic tanks in the United States ${ }^{15}$ compared to those in the present study. However, the comparable $\mathrm{CH}_{4}$ emission rate from the first compartment of septic tanks in the present study to the $\mathrm{CH}_{4}$ emission from the whole septic tanks in the United States ${ }^{29}$ can be explained by the different conditions inside the septic tanks. The average of liquid temperature, COD of liquid layer, and ORP of septic tanks in the study in United States were $17.9{ }^{\circ} \mathrm{C}, 249.7 \mathrm{mg} / \mathrm{L}$, and $-196.6 \mathrm{mV}$, respectively. ${ }^{29}$ As shown in Table 1 , the ORP in the present study was significantly lower, and liquid temperature and COD concentration of the liquid layer were significantly higher in the present study $(p<0.001$ for all, $t$ test). These conditions may have contributed to a larger $\mathrm{CH}_{4}$ production, and could have been caused by long septage storage conditions and high ambient temperatures. The median septage storage period and ambient temperature of ST1-ST10 in the present study were 9.5 years and $34-39{ }^{\circ} \mathrm{C}$, respectively, whereas those in Diaz-Valbuena et al. were 6.5 years and 6-20 ${ }^{\circ} \mathrm{C}$, respectively. ${ }^{29}$ Therefore, the more suitable conditions inside septic tanks potentially caused higher emission rates per unit organic loading of blackwater septic tanks in the present study than those of domestic wastewater septic tanks.

The IPCC emission factors are presented as per-capita $(25.5$ $\mathrm{g}-\mathrm{CH}_{4} / \mathrm{cap} /$ day $)$ and per-BOD-removed (0.6 $\mathrm{g}-\mathrm{CH}_{4} / \mathrm{g}$ BOD). ${ }^{10}$ The per-capita $\mathrm{CH}_{4}$ emission rate obtained in the present study was, even at maximum estimates, significantly smaller than the IPCC's value as mentioned above. The IPCC emission factors were originally estimated as per-BOD- removed emission factors, and then converted to per-capita emission factors based on an $85 \mathrm{~g} / \mathrm{cap} /$ day BOD loading of domestic wastewater into a lagoon and a 50\% BOD removal. However, as previously mentioned, septic tanks in Hanoi and in many low- and middle-income countries often receive only blackwater. JICA and Nippon Koei, ${ }^{22}$ and Montangero and Strauss $^{38}$ reported BOD loading of blackwater as $11.2 \mathrm{~g} / \mathrm{cap} /$ day and $45 \mathrm{~g} / \mathrm{cap} /$ day (as excreta), respectively. Although the reported values have a large gap, they are still much smaller than the BOD loading used for the IPCC per-capita emission factor. Furthermore, in Hanoi, BOD removal efficiency of septic tanks significantly decreased according to the septage storage period. ${ }^{19}$ Long storage periods might result in removal efficiency lower than $50 \%$, used by IPCC to convert emission factors. Although the present study did not obtain influent loading and BOD removal values, these factors might cause the significant difference of per-capita emission factors between the present study and IPCC. Further studies are required to investigate the correlation between BOD loading and removal, and emission rates.

In conclusion, the present paper studied GHG emissions from septic systems that receive only blackwater in Hanoi. The measured $\mathrm{CH}_{4}$ and $\mathrm{CO}_{2}$ emission rates from the first compartment of septic systems in Hanoi in summer were $11.92 \pm 4.52$ and $20.24 \pm 9.15 \mathrm{~g} / \mathrm{cap} /$ day, respectively, whereas those of $\mathrm{N}_{2} \mathrm{O}$ were at negligible levels. Based on these emission rates from the first compartment, the minimum, middle, and maximum estimates of $\mathrm{CH}_{4}$ emissions from all compartments of septic systems were obtained. The minimum estimates of the $\mathrm{CH}_{4}$ emission rates of the present study were comparable to the emission rates of septic systems in the United States, even though the septic tanks in the present study received only blackwater whereas those in the United States received black and graywater. The substantial emissions in the present study could be attributed to significantly lower ORP, higher COD concentrations, and longer septage storage periods in our study. Our results suggest that lower ORP and higher biodegradable carbon mass in association with longer septage storage periods are key conditions for $\mathrm{CH}_{4}$ emissions from septic systems. Therefore, controlled or regular septage emptying could contribute to improve not only the removal efficiency of septic tanks but also to reduce GHG emissions from septic tanks. Still, the collected septage possibly emits GHGs. Controlled septage emptying in combination with septage treatment and disposal in a GHG-mitigating manner, including biogas recovery, could reduce overall emissions. Thus, our results will contribute to estimating global GHG emissions from blackwater septic systems and provide essential information for mitigating emissions.

This study has some limitations, such as the abovementioned lack of monitoring GHG emissions from the second and third compartments of septic tanks and the influent organic loading due to the difficulty in sampling. For a better estimation of GHG emissions from the entire septic system, measurements from all compartments are required in future studies. For a more detailed comparison with the IPCC emission factor that is significantly greater than the maximum estimates of $\mathrm{CH}_{4}$ emission from all compartments of septic systems in the present study, the emission rates should be associated with influent loadings in future studies. Moreover, the present study was conducted only in summer $\left(26-33^{\circ} \mathrm{C}\right)$ with a limited difference in liquid temperature, and the seasonal variability with a larger temperature difference might 
affect the GHG emissions of septic systems. As the design and operating conditions of septic systems vary according to regions and there are other types of anaerobic onsite sanitation technologies in low- and middle-income countries, GHG emission rates should be studied in different regions with different technologies for a broader understanding of GHG emissions from onsite sanitation worldwide. Furthermore, uncontrolled septage management causes GHG emissions, requiring further studies on GHG emissions after emptying septage. Nevertheless, our successful measurement of GHG emission rates in association with conditions of septic systems contributes to society by providing the first characteristics and influential factors of GHG emissions from septic systems.

\section{ASSOCIATED CONTENT}

\section{SI Supporting Information}

The Supporting Information is available free of charge at https://pubs.acs.org/doi/10.1021/acs.est.0c03418.

Floating chamber design (Text S1); characteristics of surveyed septic tanks (Table S1); effluent characteristic (Table S2); septage composition and relevant septic tanks conditions of ST1-ST10 (Table S3); slopes and $R^{2}$ values of regression analysis for $\mathrm{CH}_{4}$ and $\mathrm{CO}_{2}$ concentrations derived from the floating chamber (Table S4); concentrations of $\mathrm{CH}_{4}, \mathrm{CO}_{2}, \mathrm{CO}, \mathrm{N}_{2} \mathrm{O}$, and $\mathrm{NH}_{3}$ accumulated in the floating chamber at $t=60$ min (Table S5); an example of linear regression analysis for emission rate based on the increase of inner concentration in the floating chamber (Figure S1); the relationship between $\mathrm{C}-\mathrm{CH}_{4}$ and $\mathrm{C}-\mathrm{CO}_{2}$ of emission rates from the first compartment of septic tanks (Figure S2); correlation between $\mathrm{CH}_{4}$ emission rate and $\mathrm{DO}$, liquid temperature of septage, and volume of settled solids for septic tanks (Figure S3); and correlation between septage storage period and DO and BOD mass of septage (Figure S4) (PDF)

\section{AUTHOR INFORMATION}

\section{Corresponding Author}

Hidenori Harada - Graduate School of Asian and African Area Studies, Kyoto University, Kyoto 606-8501, Japan; (1) orcid.org/0000-0002-7685-7751;

Email: harada.hidenori.8v@kyoto-u.ac.jp

\section{Authors}

Loi Tan Huynh - Graduate School of Engineering, Kyoto University, Kyoto 606-8501, Japan; (1) orcid.org/00000001-8339-2537

Shigeo Fujii - Graduate School of Global Environmental Studies, Kyoto University, Kyoto 606-8501, Japan

Lien Pham Hong Nguyen - School of Environmental Science and Technology, Hanoi University of Science and Technology, Hanoi 10000, Vietnam

Thu-Huong Thi Hoang - School of Environmental Science and Technology, Hanoi University of Science and Technology, Hanoi 10000, Vietnam

Hai Trung Huynh - School of Environmental Science and Technology, Hanoi University of Science and Technology, Hanoi 10000, Vietnam

Complete contact information is available at: https://pubs.acs.org/10.1021/acs.est.0c03418

\section{Notes}

The authors declare no competing financial interest.

\section{ACKNOWLEDGMENTS}

This study was funded by a grant from the Japan Society for the Promotion of Science KAKENHI (no. 16H02748) and Bill \& Melinda Gates Foundation (OPP1212310). The authors acknowledge the Institute for Agriculture Environment, Hanoi, for supporting gas analysis, and the students of the School of Environmental Science and Technology, Hanoi University of Science and Technology, for supporting our field survey.

\section{REFERENCES}

(1) Progress on Drinking Water, Sanitation and Hygiene: 2017 Update and SDG Baselines; WHO and UNICEF: Geneva, 2017.

(2) Sotelo, T. J.; Satoh, H.; Mino, T. Assessing wastewater management in the developing countries of Southeast Asia: Underlining flexibility in appropriateness. J. Water Environ. Technol. 2019, 17, 287-301.

(3) Brandes, K.; Schoebitz, L.; Nguyen, V. A.; Strande, L. SFD Promotion Initiative-Hanoi, Vietnam-Final Report; Eawag: Dübendorf, 2016.

(4) Anh, T. N. Q.; Harada, H.; Fujii, S.; Anh, P. N.; Lieu, P. K.; Tanaka, S. Preliminary analysis of phosphorus flow in Hue Citadel. Water Sci. Technol. 2016, 73, 69-77.

(5) Naing, W.; Harada, H.; Fujii, S.; Hmwe, C. S. S. Informal Emptying Business in Mandalay: Its Reasons and Financial Impacts. Environ. Manage. 2020, 65, 122-130.

(6) USAID Indonesia Urban Water, Sanitation, and Hygiene Project (USAID IUWASH); USAID and IUWASH: Jakarta, 2012.

(7) Tchobanoglous, G.; Burton, F. L.; Stensel, H. D. Wastewater Engineering: Treatment and Reuse, 4th ed.; McGraw-Hill: New York, 2003.

(8) Cairncross, S.; Feachem, S. Environmental Health Engineering in the Tropics, 3rd ed.; Routledge: London, 2019.

(9) Doorn, M.; Liles, D.; Thorneloe, S. Quantification of Methane Emissions from Latrines, Septic Tanks, and Stagnant, Open Sewers in the World. In Non- $\mathrm{CO}_{2}$ Greenhouse Gases: Scientific Understanding, Control and Implementation; van Ham, J.; Baede, A. P. M.; Meyer, L. A.; Ybema, R., Eds.; Springer: Dordrecht, 2000.

(10) Pachauri, R. K.; Reisinger, A., Eds. Synthesis Report. Contribution of Working Groups I, II and III to the Fourth Assessment Report of the Intergovernmental Panel on Climate Change; IPCC: Geneva, 2007.

(11) United Nations Framework Convention on Climate Change Flexible GHG Data Queries. Online Database. https://di.unfccc.int/ time_series (accessed March 10, 2020).

(12) Doorn, M.; Liles, D. Quantification of Methane Emissions and Discussion of Nitrous Oxide, and Ammonia Emissions from Septic Tanks, Latrines, and Stagnant Open Sewers in the World, EPA Report EPA600/R-99-089; USEPA: Washington, DC, 1999.

(13) Robbins, D. M.; Ligon, G. C. How to Design Wastewater Systems for Local Conditions in Developing Countries; IWA Publishing: London, 2014.

(14) Koottatep, T.; Prapasriket, P.; Pussayanavin, T.; Polprasert, C. Performance of up-flow thermophilic septic tank treating blackwater. Environ. Dev. Sustainability 2020, 22, 3691-3700.

(15) Onsite Wastewater Treatment Systems Manual; USEPA: Washington, DC, 2002.

(16) Borchardt, M. A.; Bradbury, K. R.; Alexander, E. C., Jr.; Kolberg, R. J.; Alexander, S. C.; Archer, J. R.; Braatz, L. A.; Forest, B. M.; Green, J. A.; Spencer, S. K. Norovirus outbreak caused by a new septic system in a dolomite aquifer. Groundwater 2011, 49, 85-97.

(17) Devitt, C.; O’Neill, E.; Waldron, R. Drivers and barriers among householders to managing domestic wastewater treatment systems in the Republic of Ireland; implications for risk prevention behaviour. J. Hydrol. 2016, 535, 534-546. 
(18) Progress on Household Drinking Water, Sanitation and Hygiene 2000-2017. Special Focus on Inequalities; UNICEF and WHO: New York, 2019.

(19) Harada, H.; Dong, N. T.; Matsui, S. A measure for provisionaland-urgent sanitary improvement in developing countries: septic-tank performance improvement. Water Sci. Technol. 2008, 58, 1305-1311.

(20) Population and Housing Census 2019 Report; GSO: Hanoi, 2019.

(21) Vietnam-Urban Wastewater Review (Vol. 2): Performance of the Wastewater Sector in Urban Areas: A Review and Recommendations for Improvement. In East Asia and the Pacific Region Urban Sanitation Review; World Bank Group: Washington, DC, 2013.

(22) JICA Survey on Examination of Monitoring Methodology for Indicator of SDG 6.3.1 in Vietnam Final Report; JICA and Nippon Koei: Tokyo, 2019.

(23) Approving the Regulation on the System and Facilities of Water Supply and Discharge in Households, Decree 47/1999/QD-BXD; Ministry of Construction (MOC): Hanoi, 1999.

(24) Pham, N. A. Study on Household Wastewater Characterization and Septic Tanks' Function in Urban Areas of Vietnam. Ph.D. Thesis; Kyoto University: Kyoto, 2014.

(25) Scheduled Emptying Services as an Entry Point for Change; SNV: The Hague, 2019.

(26) Crites, R.; Tchobanoglous, G. Small and Decentralized Wastewater Management Systems; McGraw-Hill: New York, 1998.

(27) Hutchinson, G. L.; Livingston, G. P. Use of Chamber Systems to Measure Trace Gas Fluxes. In Agricultural Ecosystem Effects on Trace Gases and Global Climate Change; Harper, L. A.; Moiser, A. R.; Duxbury, J. M.; Rolston, D. E., Eds.; Agronomy Society of America: Madison, 1993.

(28) Parkin, T. B.; Venterea, R. T. Chamber-Based Trace Gas Flux Measurements. In Sampling Protocols; Follett, R. F., Ed.; USDA: Washington, DC, 2010.

(29) Diaz-Valbuena, L. R.; Leverenz, H. L.; Cappa, C. D.; Tchobanoglous, G.; Horwath, W. R.; Darby, J. L. Methane, carbon dioxide, and nitrous oxide emissions from septic tank systems. Environ. Sci. Technol. 2011, 45, 2741-2747.

(30) Daelman, M. R. J.; van Voorthuizen, E. M.; van Dongen, U. G. J. M.; Volcke, E. I. P.; van Loosdrecht, M. C. M. Methane emission during municipal wastewater treatment. Water Res. 2012, 46, 36573670.

(31) Gold, M.; Harada, H.; Therrien, J. D.; Nishida, T.; Cunningham, M.; Semiyaga, S.; Fujii, S.; Dorea, C.; Nguyen, V.-A.; Strande, L. Cross-country analysis of faecal sludge dewatering. Environ. Technol. 2018, 39, 3077-3087.

(32) Truhlar, A. M.; Rahm, B. G.; Brooks, R. A.; Nadeau, S. A.; Makarsky, E. T.; Walter, M. T. Greenhouse Gas Emissions from Septic Systems in New York State. J. Environ. Qual. 2016, 45, 11531160.

(33) Inventory of U.S. Greenhouse Gas Emissions and Sinks: 19902008; USEPA: Washington, DC, 2010.

(34) Lewin, K.; Blakey, N. C.; Cooke, D. A. The Validation of Methodology in the Determination of Methane in Water-Final Report; Water Research Centre: Buckinghamshire, 1990.

(35) Koné, Y. J. M.; Abril, G.; Delille, B.; Borges, A. V. Seasonal variability of methane in the rivers and lagoons of Ivory Coast (West Africa). Biogeochemistry 2010, 100, 21-37.

(36) Somlai, C.; Knappe, J.; Gill, L. Spatial and temporal variation of $\mathrm{CO}_{2}$ and $\mathrm{CH}_{4}$ emissions from a septic tank soakaway. Sci. Total Environ. 2019, 679, 185-195.

(37) Biological Nutrient Removal (BNR) Operation in Wastewater Treatment Plants; Water Environment Federation: Alexandria, 2005.

(38) Montangero, A.; Strauss, M. Faecal Sludge Treatment; Eawag: Dübendorf, 2002. 